selbstbewußten kleinen und kleinsten Fürstentümern und reichsfreien Stadtstaaten zerrissenen „heiligen römischen Reich deutscher Nation“ daraus entwickelte, das erschien zunächst als eine geistige Fortsetzung des vom Kriege hervorgerufenen Chaos.

\title{
Die Oper an den großen Höfen
}

Die großen Höfe wie Wien und München, dazu Dresden und später auch Stuttgart, konnten sich den Luxus leisten, Hochburgen der italienischen Oper zu werden ${ }^{1}$. Hier kam es, allerdings als Ausnahme, mit der DAFNE von Giovanni Andrea Bontempi und Marco Giuseppe Peranda (Dresden 1671) zu einer Annäherung italienischer und deutscher Stilmerkmale (s. oben). In Wien aber, am Kaiserhof, an dem die italienische Oper am längsten zu Hause war und darum am festesten im Sattel saß, gelang es dem Hofkapellmeister Johann Joseph Fux (1660-1741) als einzigem, der Oper, ohne den Boden der Gattung zu verlassen, nicht nur selbst einen eigenen Stempel aufzudrücken, sondern auch die beiden jüngeren, unter ihm in der Hofkapelle tätigen italienischen Opernkomponisten Antonio Caldara (1670-1736) und Francesco Conti (1682-1732) in dessen Bann zu ziehen, so daß man für den Anfang des 18. Jahrhunderts von einer spezifischen Wiener Schule der italienischen Oper sprechen darf. Als ihr Prototyp kann die schon zu ihrer Zeit berühmte „festa teatrale" Fuxens COSTANZA E FORTEZZA (Beständigkeit und Festigkeit; über einen Text von Pietro Pariati) ${ }^{2}$ gelten, die zur Feier des Geburtstages der Kaiserin Elisabeth Christina und der Krönung Kaiser Karls VI. zum König von Böhmen 1723 in Prag aufgeführt wurde. Ihren großen, in der italienischen Oper der Zeit ungebräuchlichen Reichtum an Chören der verschiedensten Art verdankt sie ihrem Charakter als festliches, höfisches Gelegenheitswerk, der auch textlich hie und da und vor allem an den Aktschlüssen zum Ausdruck gebracht wird; der ganz persönliche Stil des Komponisten aber zeigt sich in der konsequenten Durchdringung der durchaus modernen Formenwelt dieser Oper mit strenger Kontrapunktik in Chor- und Instrumentalsätzen, vor allem aber in der häufigen gleichberechtigten Einbeziehung der Solostimmen in das kontrapunktische Geflecht des nicht nur begleitenden Orchesters.

\section{Die „frühdeutsche“ Oper an Höfen und in Städten}

Längst vor dieser selbständigen musikalisch-stilistischen Prägung der fremden Gattung in der unmittelbaren Nachbarschaft ihres Heimatlandes hatte man jedoch schon in anderen Teilen des deutschen Reiches versucht, sie sich mit den zur Verfügung stehenden bescheideneren Mitteln nunmehr auch allgemein geistig, d. h. vor allem sprachlich, anzuverwandeln. Die Auseinandersetzung mit dem von den großen Höfen her lockenden und doch so unerreichbaren Vorbild brach

1 Vgl. Die barocke Adels- und Fürstenoper..., oben S. $20 \mathrm{ff}$.

2 Veröffentlicht in: Denkmäler der Tonkunst in Österreich VII. 